Limnological Review 10, 3-4: 163-172

DOI 10.2478/v10194-011-0019-z

\title{
Oxygen conditions and trophic state of Lake Głębokie (Szczecin, Poland) in the years 2008-2010
}

\author{
Arkadiusz Nędzarek, Agnieszka Tórz, Jacek Kubiak \\ Westpomeranian University of Technology in Szczecin, Department of Hydrochemistry and Water Protection, K. Królewicza 4H, 71- \\ 550 Szczecin, Poland, e-mail: arkadiusz.nedzarek@zut.edu.pl
}

\begin{abstract}
The research in Lake Głębokie was conducted in the years 2008-2010. Sampling from three selected sites was designed in such a way that vertical profiles of the characteristics of interest were obtained. Measurements were performed to determine the content of dissolved oxygen, oxygen saturation expressed as a percentage, water temperature, total phosphorus, chlorophyll a, dry seston mass, and Secchi disk depth. During the course of a year, water temperature varied from $0.58^{\circ} \mathrm{C}$ to $24.72^{\circ} \mathrm{C}$. However, a permanent thermal stratification was not observed in the summer season due to complete water mixing. Dissolved oxygen concentrations in the water varied within a range that started at hard-to-measure insignificant values and reached up to $9.63 \mathrm{mg} \mathrm{O}_{2} \mathrm{l}^{-1}$, while oxygen saturation reached a maximum of $116 \% \mathrm{O}_{2}$. At the same time, it was observed that oxygen conditions gradually worsened as the depth became greater. The largest oxygen deficits occurred in the winter season of 2009-2010. The oxygen conditions were typical for an eutrophic lake. Its high trophic state was confirmed by an analysis performed using the method proposed by Carlson (1977) as well as by an analysis performed according to the directives of the OECD (1982). The trophic state of this lake is borderline eutrophic and hypertrophic. The oxygen conditions found in this lake ought to be seen as not beneficial to fish.
\end{abstract}

Keywords: Lake Głębokie, trophic state, oxygen, chlorophyll, phosphorus, organic carbon

\section{Introduction}

The concentration of dissolved oxygen in water is a deciding factor, which determines the chemical and biological state of a lake. The degree of dissolved oxygen saturation depends on the processes that enrich lake water in oxygen (primarily photosynthesis) and those depleting oxygen, such as the decomposition of organic matter (Wetzel 2001). High primary production causes that percent saturation of dissolved oxygen in the epilimnion is high. High primary production often depletes dissolved oxygen in the hypolimnion and the metalimnion due to aerobic mineralization of biomass present there in the form of sediment. Changes in the content of dissolved oxygen that are observed in the vertical profile occur not only in deep lakes. In fact, they are primarily observed in shallow polymictic lakes. It is in these lakes that, in spite of the mixing of their waters all year long, an intense decomposition of organic matter may lead to substantial oxygen deficits (Gächter 1987; Cooke et al. 1993; Müller and Stadelmann 2004).
The dissolved oxygen content takes on a special meaning, because it is a factor that fundamentally determines the living conditions of the animal species in lake water habitats. This is especially applicable to fish (Müller and Stadelmann 2004). With this in mind, an assessment of oxygen conditions was undertaken for the small and shallow Lake Głębokie. The lake is important due to the necessity of the protection of water resources. It also has an important social function the lake serves as a leisure and recreation area for the residents of the City of Szczecin.

In this paper, the trophic state of the lake was also assessed by applying the method proposed by Carlson (1977) as well as by an analysis performed according to the directives of the OECD (1982). The dependence of oxygen conditions on the main factors that determine the content of dissolved oxygen in water, such as chlorophyll $a$, dry seston mass and total organic carbon (TOC), were considered. The impact of the recorded oxygen conditions on fish species also assessed. 


\section{Material and methods}

Lake Głębokie is located within the administrative boundaries of the City of Szczecin, adjacent to the Puszcza Wkrzańska primeval forest and the Wzgórza Warszewskie Hills. The lake is located in a post-glacial rill-type valley, which is a long U-shaped subglacial valley formed under the ice in past glacial ages. This lake is a body of water that forms its own endorheic basin. The lake is recharged only by water from precipitation and by underground water. The lake is connected by a manmade underground channel with Lake Goplany, which makes additional recharge of the lake possible by waters from the Osówka River. Another means of recharging Lake Głębokie is through a similar channel connection with water from the Mała Gunica River. The lake is a popular local attraction, a place for leisure and recreation. There is a tourist trail around the lake for walking and running. There is a beach at the southern end of the lake, which is maintained by the City of Szczecin. Data on the morphometric characteristics and the catchment of the lake are summarized in Table 1.

The research in Lake Głębokie was conducted from October of 2008 until May of 2010. Measurements took place on ten different dates, scheduled roughly every 2 months. Samples from three selected sites were collected in order to obtain vertical profiles of the characteristics of interest. Vertical profiles (cross sections) were obtained (Fig. 1) by performing measurements every $1 \mathrm{~m}$ of height of the water column to determine the content of dissolved oxygen, oxy-

Table 1. Morphometric data and catchment data for Lake Głębokie (IMiGW 1991)

\begin{tabular}{|c|c|c|}
\hline Characteristic or indicator & Unit & Value \\
\hline Lake surface area & ha & 31.3 \\
\hline Maximum length & \multirow{4}{*}{$\mathrm{m}$} & 1,550 \\
\hline Maximum width & & 300 \\
\hline Mean width & & 202 \\
\hline Shoreline length & & 3,950 \\
\hline Shoreline development index & & 1.99 \\
\hline Maximum depth & \multirow{2}{*}{$\mathrm{m}$} & 5.0 \\
\hline Mean depth & & 2.4 \\
\hline Volume & dam $^{3}$ & 751.0 \\
\hline Total catchment area & \multirow{5}{*}{ ha } & 162 \\
\hline Direct catchment area & & 134 \\
\hline Woodland area & & 128 \\
\hline Clearings in the forest & & 2.7 \\
\hline Built-up area & & 30 \\
\hline
\end{tabular}

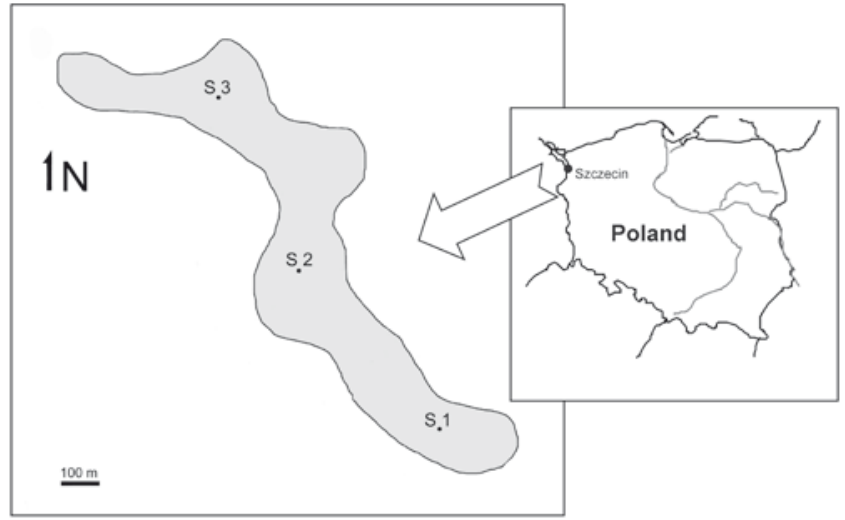

Fig. 1. Location of water sampling sites (S1-S3) in Lake Głębokie in the years 2008-2010

gen saturation expressed as a percentage, and water temperature using an HI9828 multiparametric probe made by HANNA Instruments. Secchi disk depth was also measured. The remaining hydrochemical data were generated by testing the lake water samples collected at a depth of $0.5 \mathrm{~m}$ under the surface of the lake, at a depth of $3 \mathrm{~m}$, and from the benthic layer at $0.5 \mathrm{~m}$ above the lake's bottom.

Laboratory methods recommended by the APHA (1995) were applied. Chlorophyll $a$ and total phosphorus were determined by colorimetric methods using a UV-VIS spectrometer of type Lamda 25, made by Perkin Elmer. Chlorophyll $a$ was determined by applying the method of extraction with acetone $(\lambda$ $=665 \mathrm{~nm}$ ). Total phosphorus, after an initial conversion of the sample to inorganic form using potassium persulfate, was determined by using ammonium molybdate with ascorbic acid as a reducer $(\lambda=882$ $\mathrm{nm})$. Total organic carbon was determined by using a carbon analyzer made by Shimadzu TOC-V $\mathrm{V}_{\mathrm{CSN}}$. Dry seston mass was determined by weighing.

Statistical analysis was performed on the measurement results that were obtained. Coefficients of Pearson's linear correlation were calculated for relationships between selected hydrochemical data at a significance level of 0.05 . The software used was Statistica 9.0 (StatSoft Inc. 2009).

\section{Results}

During the period of time when the research was conducted, the water temperature in Lake Głębokie varied within a wide range from $0.58^{\circ} \mathrm{C}$ to $24.72^{\circ} \mathrm{C}$ (with the average being $10.6^{\circ} \mathrm{C}, \mathrm{SD}=6.16$ ) (Table 2). 
Table 2. Variability, mean, and standard deviation (SD) of hydrochemical data for Lake Głębokie during the period from October of 2008 to May of 2010

\begin{tabular}{|c|c|c|c|c|c|c|c|c|}
\hline & $\mathrm{T}$ & $\mathrm{O}_{2}$ & $\mathrm{O}_{2}$ & $\mathrm{TP}$ & $\mathrm{TOC}$ & Chlorophyll $\mathrm{a}$ & Seston & Visibility \\
\cline { 2 - 9 } & ${ }^{\circ} \mathrm{C}$ & $\mathrm{mg} \mathrm{l}^{-1}$ & $\%$ & $\mathrm{mg} \mathrm{l}^{-1}$ & $\mathrm{mg} \mathrm{l}^{-1}$ & $\mu \mathrm{g} \mathrm{l}^{-1}$ & $\mathrm{mg} \mathrm{l}^{-1}$ & $\mathrm{~m}$ \\
\hline Minimum & 0.58 & 0.20 & 1.60 & 0.100 & 12.4 & 1.0 & 17.8 & 0.7 \\
\hline Maximum & 24.72 & 9.63 & 116.0 & 0.666 & 69.8 & 114.5 & 68.0 & 2.6 \\
\hline Average & 10.60 & 4.54 & 43.29 & 0.345 & 22.9 & 26.2 & 33.7 & 1.5 \\
\hline SD & 6.16 & 2.62 & 29.05 & 0.184 & 17.4 & 23.7 & 11.1 & 0.6 \\
\hline
\end{tabular}

T - Temperature; TP - Total Phosphorus; TOC - Total Organic Carbon

However, a permanent thermal stratification was not observed in the summer season. In the summer, water temperature in the vertical cross-section ranged from about $16^{\circ} \mathrm{C}$ in the benthic layer up to about $24^{\circ} \mathrm{C}$ in the surface layer. The situation was similar at all of the research sites (Fig. 2), quite the way it was observed at research site no. 1 (Fig. 3 ).

The lowest water temperatures were recorded in the winter of 2010. It was then that an ice sheet covered the lake continuously from mid-January till about March 10. Under the ice sheet, at $2 \mathrm{~m}$ below the surface in the vertical cross-section, a temperature gradient of about $1.3^{\circ} \mathrm{C} \mathrm{m}^{-1}$ was recorded.

Oxygen conditions were characterized by substantial variability, both seasonal as well as in the vertical cross-section (Table 2; Figs. 3, 4). The dissolved oxygen concentration range was from infinitesimal to $9.63 \mathrm{mg} \mathrm{O}_{2}{ }^{-1}$, and percent oxygen saturation reached

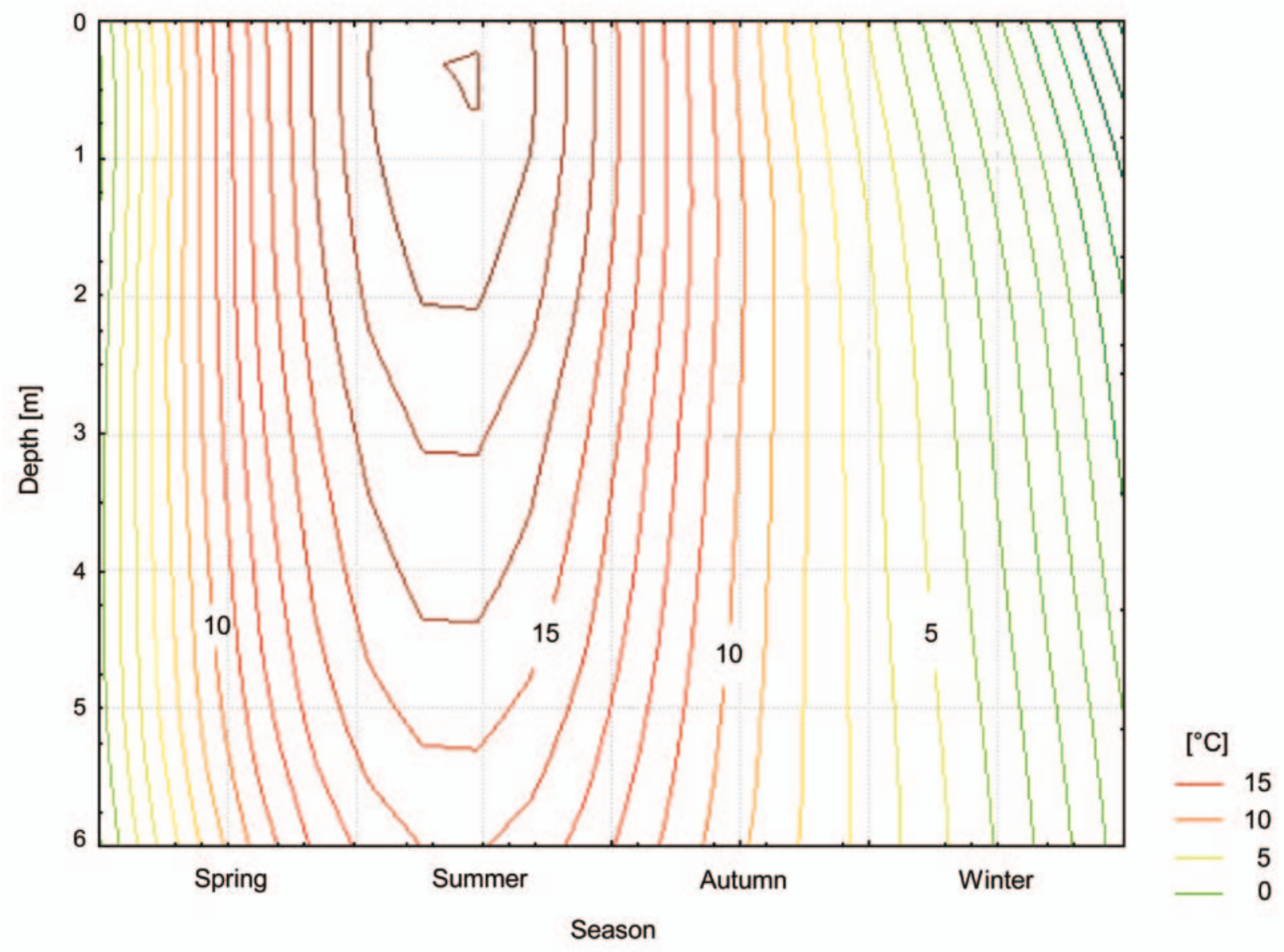

Fig. 2. Seasonal variability in water temperature in Lake Głębokie during the research period 

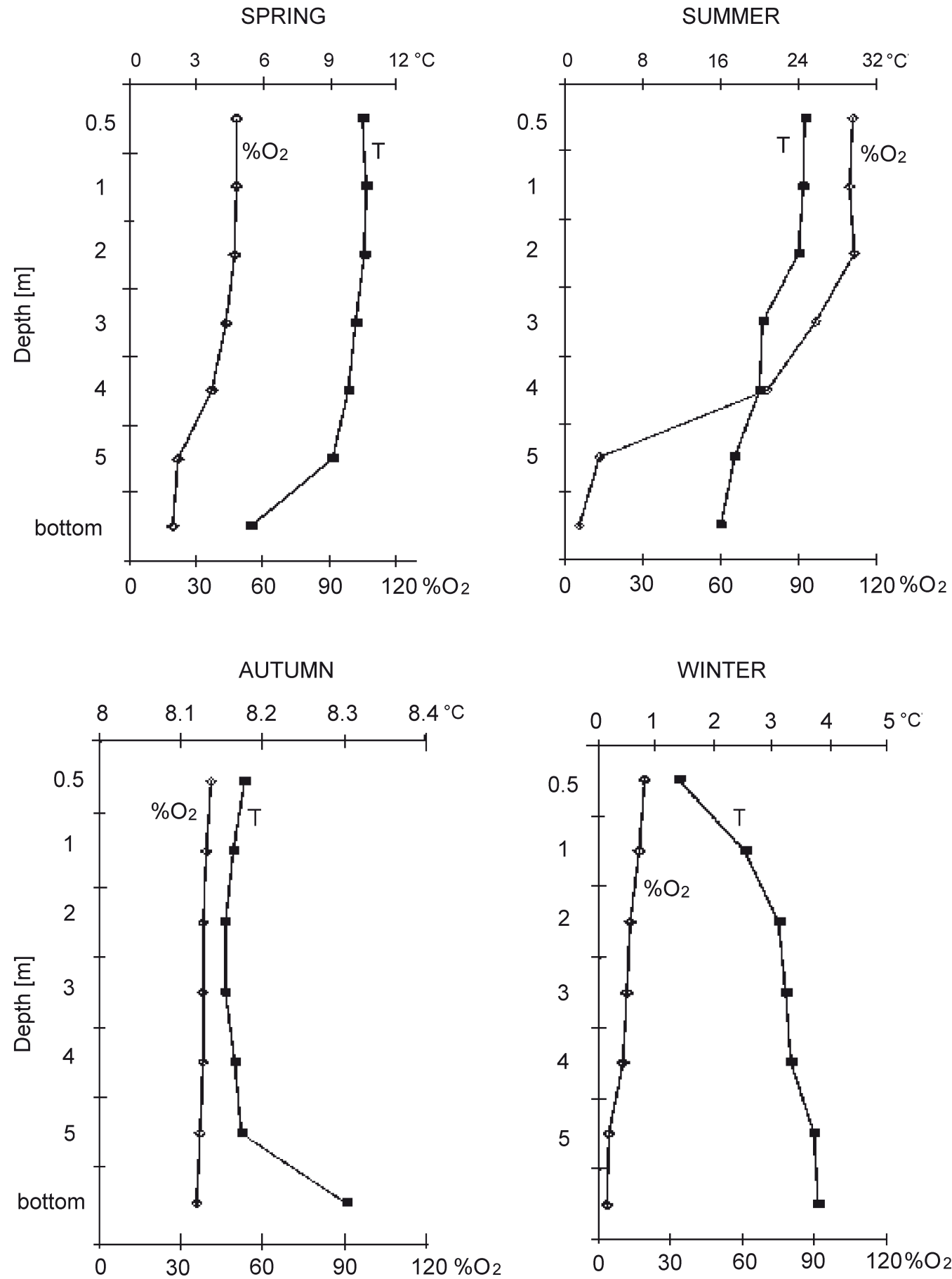

Fig. 3. Seasonal variability in water temperature $(\mathrm{T})$ and oxygen saturation of water expressed as a percentage $\left(\% \mathrm{O}_{2}\right)$ at sampling site $\mathrm{S} 1$ in Lake Głębokie during the research period 


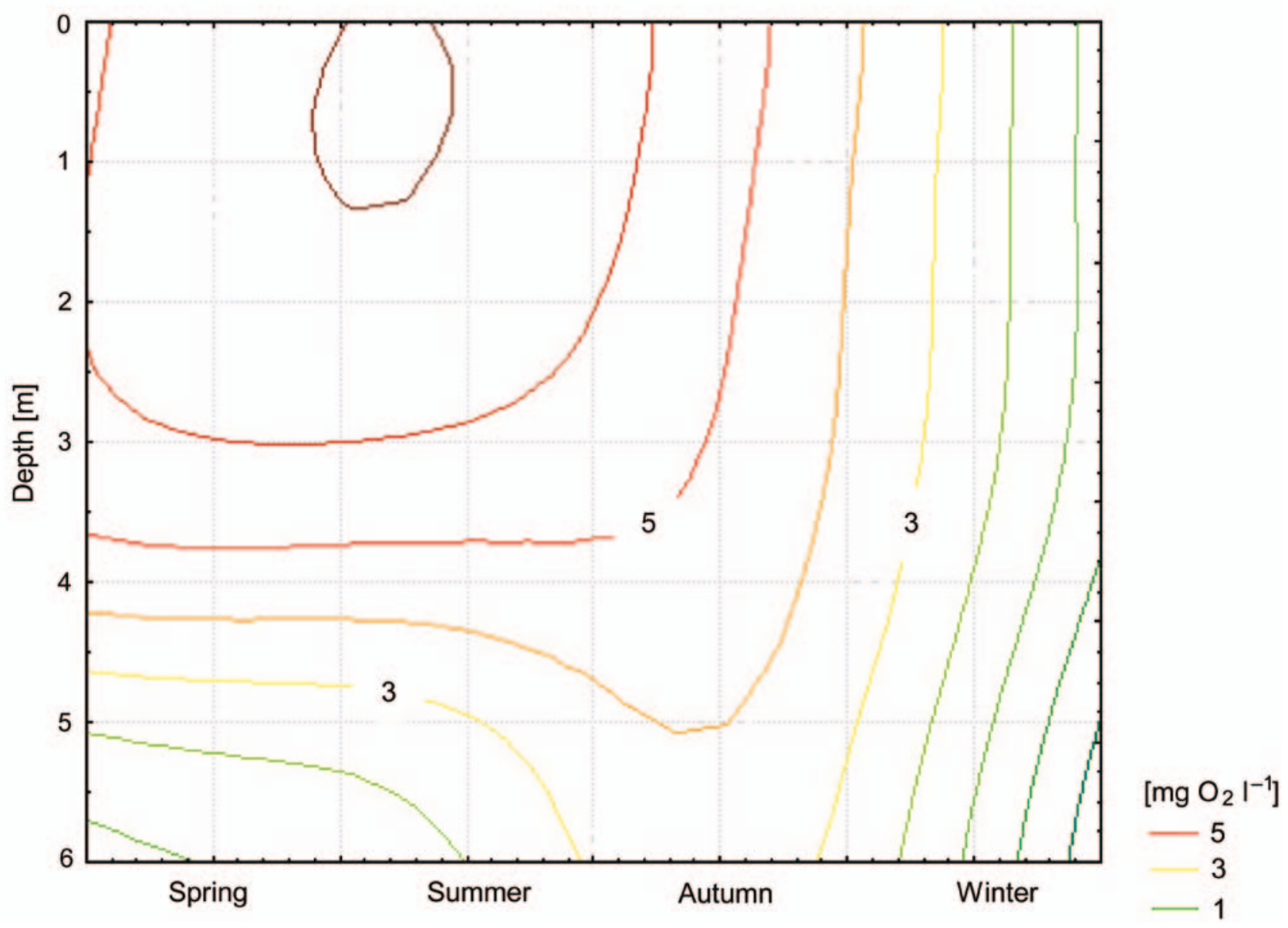

Fig. 4. Seasonal variability in the concentration of dissolved oxygen in the water in Lake Głębokie during the research period

$116 \% \mathrm{O}_{2}$. The average values of these two parameters were equal to: $4.54 \mathrm{mg} \mathrm{O}_{2} \mathrm{l}^{-1}$ and $43.29 \% \mathrm{O}_{2}$ respectively, with SD equal to 2.62 and 29.05 , respectively) (Table 2 ).

In vertical cross-sections at all of the sampling sites, it was observed that oxygen conditions gradually worsened as depth increased (Figs. 3, 4). This situation occurred during every research season, and the largest oxygen deficits occurred in the winter season of 20092010. During that period, the oxygen saturation of water did not exceed $30 \% \mathrm{O}_{2}$ (Fig. 3). The best oxygen conditions were observed during the peak vegetation season, when supersaturation with dissolved oxygen was observed in the surface water layer about $2 \mathrm{~m}$ thick. At that time, the average oxygen saturation percentage in that top water layer of the lake was about $110 \% \mathrm{O}_{2}$, with $\mathrm{SD}=3.5$. However, below the top water layer, where supersaturation with oxygen occurred, an increasing oxygen deficit was observed with increasing depth. A lack of oxygen in the benthic water layer was also noted.
Total phosphorus concentrations (TPC) varied from 0.100 to $0.666 \mathrm{mg} \mathrm{P}^{-1}$ (Table 2). It was observed that the smallest TPC values were recorded in the winter season while the largest values were recorded in the summer season. High concentrations of total phosphorus in the benthic water layer of the lake were observed to hold steady (Fig. 5).

Organic matter content was determined by detecting total organic carbon and chlorophyll $a$ in the water of the lake. Organic matter content in Lake Głębokie was high. The average concentrations of total organic carbon and chlorophyll $a$ were $26.2 \mathrm{mg} \mathrm{C}$ $\mathrm{l}^{-1}$ and $33.7 \mu \mathrm{g} \mathrm{l}^{-1}$, respectively. The concentration values varied rather broadly (Table 2 ).

The water in Lake Głębokie was characterized by high seston content as well as small Secchi disk depths (average values: $33.7 \mathrm{mg} \mathrm{l}^{-1}$ and $1.5 \mathrm{~m}$, respectively) (Table 2). 


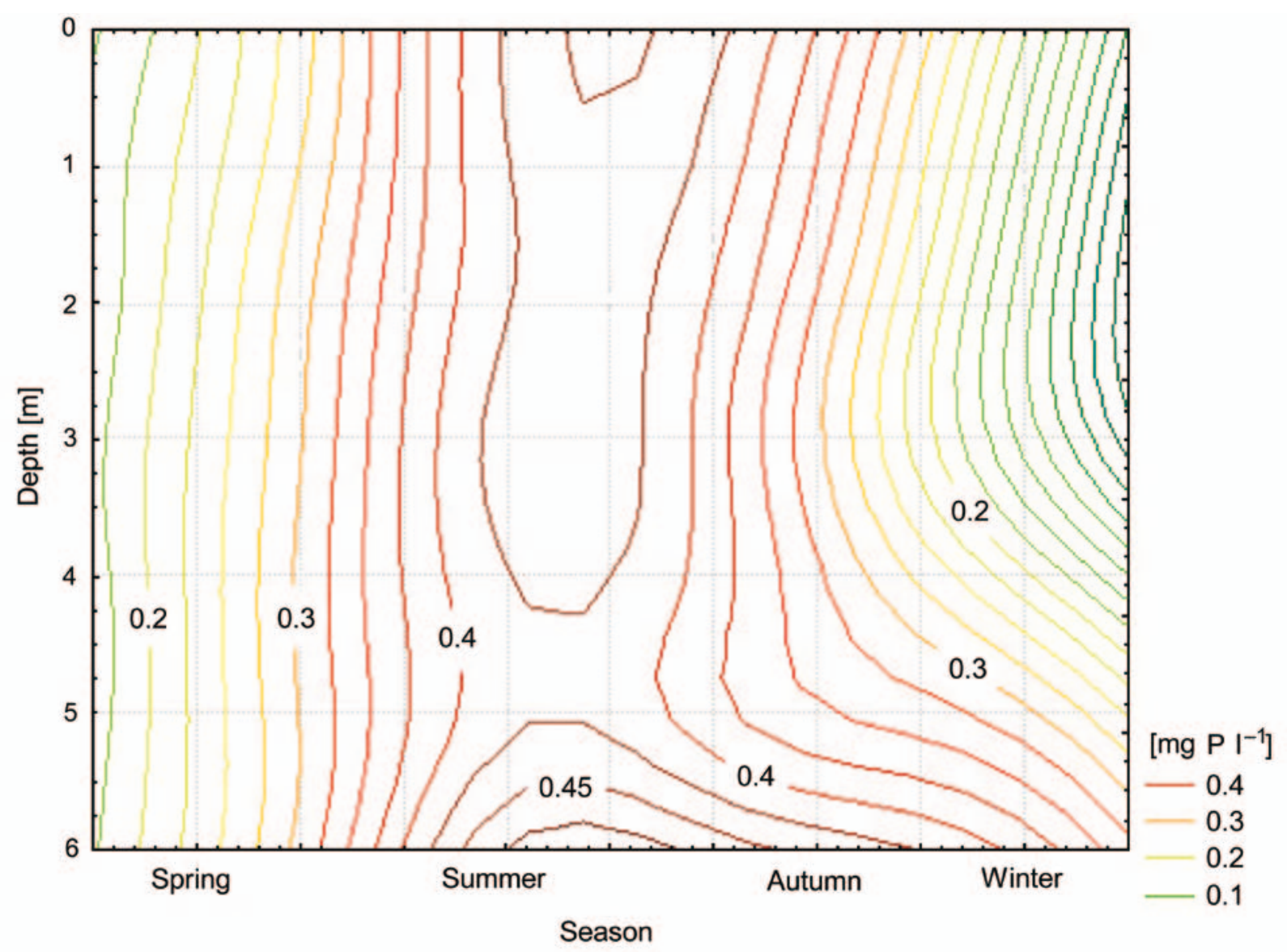

Fig. 5. Seasonal variability in the concentration of total phosphorus in the water in Lake Głębokie

\section{Discussion of Results}

The thermal conditions in Lake Głębokie are determined by its morphometric characteristics. The small depth of the lake and good exposure to the action of winds cause that the lake is prone to intense mixing of water along its entire vertical cross-section. This makes it impossible for permanent thermal stagnation to occur in the summer. Wiszniewski (1953) also classified this lake as a polymictic lake.

In spite of the complete water mixing in the lake, a clinograde oxygen profile was noted in the summer season - which is typical for eutrophic lakes. The high trophic state of Lake Głębokie was confirmed by using a method proposed by Carlson (1977). It has been shown that with regard to Secchi disk depth and the concentration of chlorophyll $a$, Lake Głębokie is an eutrophic lake. However, with regard to the concentration of total phosphorus, it is a hypertrophic lake (Fig. 6).

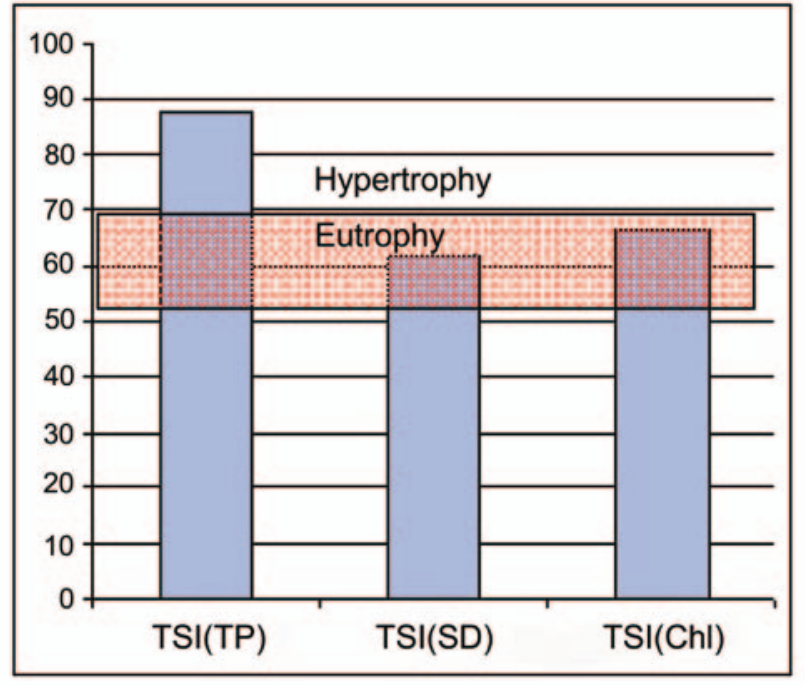

Fig. 6. Assessment of the trophic state of Lake Głębokie using the Carlson method (1977) 
However, according to recommendations issued by the OECD (1982), all of the data generated for this lake fall within ranges typical of hypertrophic lakes. For such lakes, the concentration of total phosphorus exceeds $0.100 \mathrm{mg} \mathrm{P} \mathrm{l}^{-1}$, the concentration of chlorophyll $a$ exceeds $25 \mu \mathrm{g} \mathrm{l}{ }^{-1}$, and Secchi disk depth is less than $1.5 \mathrm{~m}$. Therefore, Lake Głębokie ought to be counted among lakes, which had been affected by substantial human pressure in the 20th century, and has experienced accelerated eutrophication because of that. Accelerated eutrophication, in many extreme cases, leads to a dramatic worsening of water quality in affected lakes (Rabalais 2002).

Lake Głębokie is also listed by the Institute of Environmental Protection (IOŚ 1999) for its low water quality. The morphometry of the lake adversely affects its water quality. A small depth and a large area of the bottom of the lake being in contact with the warm waters of the epilimnion, in the absence of thermal stratification, are judged by many researchers to be the factors significantly responsible for the low quality of water in lakes (Hutchinson 1952; Vollenweider 1968). The entire bottom of Lake Głębokie remains in contact with the water of the epilimnion, thus participating in the exchange of organic and mineral matter stored in the sediments on the bottom of the lake, which by way of the complete mixing of water in the lake, may be used by autotrophes multiple times (Zdanowski 1982; Kudelska et al. 1994; Galicka et al. 2005).

This is confirmed by the high concentration of total phosphorus detected in the water layer at the bottom of the lake (Fig. 5). In this manner, the phosphorus stored in the lake is an internal source of this biogenic element. Lake Głębokie is a body of water with its own endorheic basin. In a sense, this is not good, because the lake accumulates allochtonic substances that get into it from its drainage basin (Kudelska et al. 1994).

Supersaturation with dissolved oxygen, observed during the intense vegetation season in the surface water layer about $2 \mathrm{~m}$ thick, indicates high primary production. This is confirmed by an analysis of the dependence of dissolved oxygen concentration (DOC) on chlorophyll $a$, which is an indicator of the level of primary production (Canuel and Zimmerman 1999; Ostapenia et al. 2009). In the case of this lake, a statistically significant proportional correlation between DOC and chlorophyll $a$ content (Fig. 7) was proven.

A clear decrease in the concentration of dissolved oxygen in the deeper water layers in the sum- mer season, and oxygen deficits noted during the remaining seasons in the entire vertical profile, indicate a rapid conversion of organic matter into inorganic form - organic matter produced in the lake and stored in lake bottom sediments (Sehgal and Welch 1991). An analysis of the relationship between dissolved oxygen content and total organic carbon content shows that these processes do occur in Lake Głębokie. Finally, a statistically significant inverse relationship between dissolved oxygen and total organic carbon has been show to exist (Fig. 7).

High primary production in Lake Głębokie may, at the same time, be its own significant limiting factor. According to Kufel (2001), the amount of light getting through the water is affected by algae. It has been shown for Lake Głębokie that the equations of linear regression for dry seston and chlorophyll $a$ that were found were proportional and statistically significant (Fig. 8). This leads to the conclusion, made also by Kufel and Kufel (1997), that algae is an important component of seston. At the same time, it was shown that there was an inversely proportional relationship between chlorophyll $a$ and Secchi disk depth (Fig. 8). The conclusion here is the same as that made in the paper by Kufel (2001), that the amount of light in a lake may be an important factor limiting primary production.

The oxygen conditions found in Lake Głębokie ought to be seen as not beneficial to fish. A significant decrease in dissolved oxygen content in the benthic layer of eutrophic lakes with similar oxygen conditions causes benthic feeders and plankton-eating fish to live and feed exclusively in the epilimnion and the littoral zone. In extreme cases, if the oxygen deficit persists for a very long time, even fish whose oxygen demand is the smallest (Cyprinidae and Percidae families) might die off (Alabaster and Lloyd 1982).

In addition to an oxygen deficit, another phenomenon that is also dangerous to fish is a supersaturation with dissolved oxygen. This leads, for example, to an increase in mortality of coregonidae larvae living in the surface water layer (Enz et al. 2002). Under such circumstances, fish in lakes have a limited area where living conditions are favorable to them. This applies primarily to fish species whose environmental needs are high, such as the salmon family (Alabaster and Lloyd 1982).

A negative influence of lake eutrophication on fish is also reflected by toxic algae blooms and a high $\mathrm{pH}$ (Alabaster and Lloyd 1982; Müller and Stadel- 


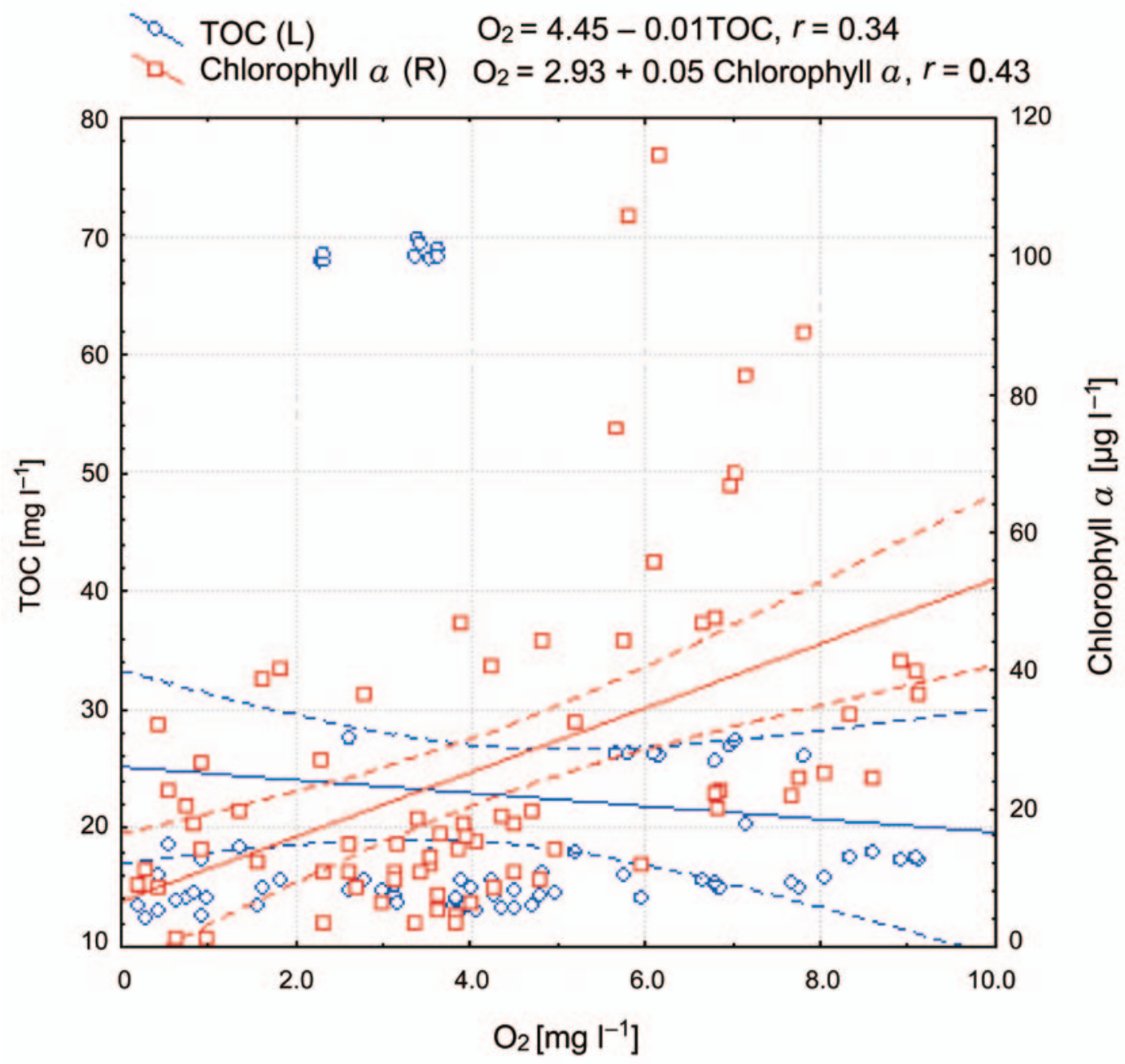

Fig. 7. Relationship between dissolved oxygen in the water and chlorophyll $a$ and total organic carbon (TOC), (statistically significant coefficients of Pearson's linear correlation $(r)$ )

mann 2004). In Lake Głębokie, a situation that is especially dangerous to fish is created when in the winter an ice sheet covers the lake for a long time. As studies have shown, cutting-off the intake of oxygen from the surrounding air in the winter leads to a dramatic decrease in dissolved oxygen content in water along the entire vertical cross-section.

\section{Summary}

The progressive eutrophication of lakes, regardless of the factors involved (natural or anthropogenic), is the main factor leading to the worsening of water quality of surface waters. Eventually, this causes an acceleration of the aging of lakes and also their disappearance. Lake Głębokie can be classified as a degraded lake. The high trophic state of such lakes impacts, in a negative way, the living conditions of animals present in the lake habitat. This especially applies to fish. This is also the case in Lake Głębokie. Therefore, an ongoing water quality monitoring program is in order. It is also recommended that a proper methodology be developed for its use and environmental protection. 


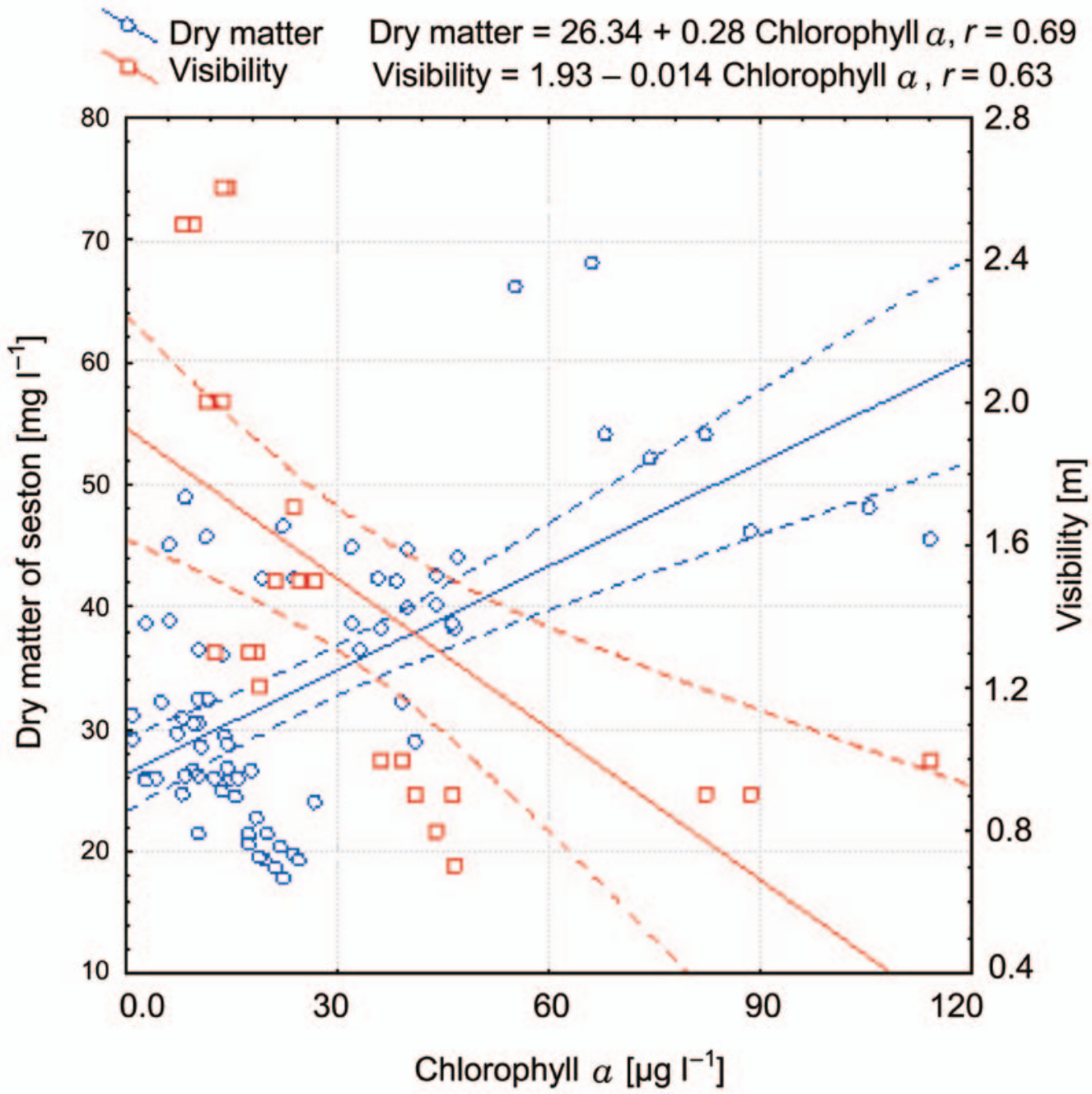

Fig. 8. Relationships between chlorophyll $a$ on the one hand and dry seston mass and Secchi disk depth in the water in Lake Głębokie on the other, (statistically significant coefficients of Pearson's linear correlation)

\section{References}

Alabaster J.S., Lloyd R., 1982, Water Quality Criteria for Freshwater Fish, Butterworths, London, p. 361.

APHA, 1995, Standard Methods for Examination of Water and Wastewater, Am. Publ. Health Assoc., Washington, p. 1200.

Canuel E., Zimmerman A., 1999, Composition of particulate organic master in the Southern Chesapeake Bay: Sources and reactivity, Estuaries 22(4): 980-994.

Carlson R. F., 1977, A trophic state index for lakes, Limnol. Oceanogr. 22(2): 361-369.

Cooke G.D., Welch E.B., Peterson S.A., Newroth P.R., 1993, Restoration and Management of Lakes and Reservoirs, CRC Press, Boca Raton, p. 548.
Enz C., Müller R., Mbwenemo B.M., Heeb J., 2002, A population dynamics model for evaluating mortality factors in Lake Hallwil withefish (Coregonus suidteri) larvae, Arch. Hydrobiol. Ergeb. Limnol. 57: 343-358.

Gächter R., 1987, Lake restoration. Why oxygenation and artificial mixing cannot substitute for a decrease in the external phosphorus loading, Schweiz. Z. Hydrol. 49: 170-185.

Galicka W., Kruk A., Penczak T., Zięba G., Koszaliński H., Tybulczuk S., 2005, Productivity of Warta river's oxbow lakes, [in:] J. Burchard (ed.), State and anthropogenic changes of water quality in Poland, Wyd. UŁ, Łódź: 225238.

Hutchinson G.E. 1957, A treatise on limnology. Geography, physic and chemistry, Chapman and Hall, London, p. 1015. 
IOŚ 1999, Raport o stanie środowiska w województwie zachodniopomorskim w latach 1997-1998 (Report on the state of the environment in Western Pomerania in the years1997-1998), IOŚ- WIOŚ Szczecin, Biblioteka Monitoringu Środowiska, Szczecin, p. 200 (in Polish).

Kudelska D., Cydzik D., Soszka H., 1994, Wytyczne monitoringu podstawowego jezior (Recommendations for basic monitoring of lakes), PIOŚ, Warszawa, p. 34 (in Polish).

Kufel I., Kufel L., 1997, Eutrophication processes in a shallow, macrophyte-dominated lake - nutrient loading to and flow trough Lake Łuknajno (Poland), Hydrobiol. 342/343: 387-394.

Kufel L., 2001, Uncoupling of chlorophyll and nutrients in lakes - possible reasons, expected consequences, Hydrobiol. 443: 59-67.

Müller R., Stadelmann P., 2004, Fish habitat requirements as the basis for rehabilitation of eutrophic lakes by oxygenation, Fisheries Manag.Ecol. 11: 251-260.

OECD 1982, Eutrophication of Waters. Monitoring, Assessment and Control, OECD, Paris, p. 154.
Ostapenia A.P., Parparov A., Berman T., 2009, Liability of organic carbon in lakes of different trophic status, Freshwater Biol. 54: 1312-1323.

Rabalais N.N., 2002, Nitrogen in aquatic ecosystems, Ambio 31(2): 102-112.

Sehgal S. H., Welch E. B., 1991, A case of unusually high oxygen demand in a eutrophic lake, Hydrobiology 209: 235-243.

StatSoft 2009, STATISTICA (data analysis software system, version 0.9. www.ststsoft.com.

Vollenweider, R.A., 1968, Scientific fundamentals of the eutrophication of lakes and flowing waters, with particular reference to nitrogen and phosphorus as factors in eutrophication, OECD Tech. Rpt. DA 5/SCI/68.27, Paris, p. 250.

Wetzel R.G., 2001, Limnology. Lake and River Ecosystems, Academic Press, San Diego, p. 1006.

Wiszniewski J., 1953, Uwagi w sprawie typologii jezior polskich (Notes on typology of Polish lakes), Pol. Arch. Hydrobiol. 1(14): 11-23 (in Polish, English summary).

Zdanowski B., 1982, Variability of nitrogen and phosphorus contents and lake eutrophication. Pol. Arch. Hydrobiol. 29 (3-4): 541-597. 